TURIZAM

Volume 25, Issue 3

$134-148$ (2021)

ORIGINAL

SCIENTIFIC PAPER

\title{
Analysis of Challenges of Private Tour Operators in Developing Successful Business: Case Study of Assam
}

\author{
Biswajit Sarmah ${ }^{A^{*}}$, Homeswar Goswami ${ }^{\mathrm{B}}$ \\ Received: July 2020 | Accepted: March 2021 \\ DOI: 10.5937/turizam25-27590
}

\begin{abstract}
Assam, the premier north eastern state of India, has a long history of hosting wildlife tours inside its world famous Kaziranga National Park since 1904. Tour operators operating from the state have been carrying millions of domestic and international tourists annually to various destinations of Assam and its adjacent states of North East India. At present, aroundseventy Government of Assam recognised Private Tour Operators and one Government tour operator under Assam Tourism Development Corporation are providing valuable services to the tourists visiting this part of the country. The present study intends to study the challenges faced by the Private Tour Operators of Assamand also to try to put forward few suggestionsfor the improvement of their business conditions. The research work is mostly based on primary data collected during the interactions with the officialsof the Private Tour Operators of Assam and few secondary data are also gathered from various printed and online publications, records of the Directorate of Tourism-Assam and various research publications. The research results determined the existence of many challengesthat Private Tour Operators need to deal with while operating from this remotest part of India. It is expected that the research results will help the Private Tour Operators of Assam in finding solutions to some of their problems and thereby improving their business conditions. This study is also believed to serve the state tourism department and policymakers to formulate plans for the development of tour operators in particular and tourism in general for the state.
\end{abstract}

Keywords: private tour operators, tourism, Assam, north east India, Kaziranga national park, package tours

\footnotetext{
Department of Management, Assam down town University, Guwahati-26, India

Faculty of Management, Assam down town University, Guwahati-26, India

Corresponding author: biswajitsarmah@gmail.com
} 


\section{Introduction}

The tourism industry has witnessed the role of tour operators as one of the principal intermediaries between the supplier of travel services and the tourists. A tour operator buys individual travel components like transportation, accommodations, food and entertainments from different suppliers and assembles those into different 'Package Tours' by adding certain value to it and sells them with its own price tag to the tourists either directly or through some retail travel agents (Swain, Mishra, 2012). Being the creator of a 'Package Tour', tour operators have to take many risks due to the very characteristics of the product itself. 'Package Tour' is a unique product which has to be sold to the tourists who cannot see or verify it beforehand and can experience it only during their journey. So, convincing a tourist without showing the product is the first big challenge for any operator. Moreover, package tours are highly perishable in nature. An unsold product on a particular date cannot be sold later on. In the world of uncertainty, any socio-economic, political disturbance and natural calamity can affect the tourism market in a big way. Inspite of all the odds, the tour operators around the world have been able to contribute immensely in shaping the tourism industry as one of the fastest growing and highest employment generating industries in the world. Tour operators operate in various forms like Inbound, Outbound, Domestic and Ground Operators. They are specialized professionals offering services to various national and international travelers and also sometimes work as ground handling agents. All these different classes of tour operators either operate privately or as government or government undertaking concerns. Private Tour Operators are those travel companies owned and managed by private individuals established in the form of a sole proprietorship business, partnership firm or a limited company. Government Tour Operators are organizations established and operated by Tourism Departments of Central or State Governments to facilitate travel related services to the tourists. Today's tourism industry is largely handled by the Private Tour Operators while the government tourism departments mainly look after the creation and maintenance of tourism infrastructures along with framing rules and regulations for the entire industry. Therefore, private operators have to provide quality services to the tourists in carrying out the responsibility of development of tourism still abiding the rules and regulations framed by the governments of respective countries. But, the rapid growth of users of Internet and other social media platforms is gradually diminishing the role of tour operators as the principal intermediary between the supplier of travel services and the tourists. Modern tech-savvy tourists prefer direct dealing with the suppliers of tourism components rather than purchasing whole Package Tour mainly to cut the cost of travel and to keep the itinerary flexible. Moreover, large online travel companies have overpowered small tour operators by means of their resources and heavy investment in technologies. Besides these, there are many issues like global climate change, rise in fuel price, terrorism, and economic conditions etc. which have challenged the very existence of the Tour Operators across nations. The Private Tour Operators of Assam also have similar challenges before them while operating from the remotest part of India's north east. This study is aimed at finding the challenges faced by the Private Tour Operators operating from Assam so that some suitable suggestions can be put forward both for the operators and the policy makers for tourism in Assam so that the tour operation business in the state can flourish. 


\section{Tour Operators of Assam}

The Register Book with the Directorate of Tourism, Government of Assam (as of May 2018) shows that there are 70 numbers of Registered Private Tour Operators operating from 13 different districts across Assam. Amongst them 29 operators have got Final Registrations and 41 have got Provisional Registrations. Around 73\% of Private Tour Operators are operating from Guwahati, which is the capital city of Assam and the primary economic hub of entire north eastern region of India.

Besides these Private Tour Operators there is one public sector Tour Operator in Assam with the name Red River Tours \& Travels, which also provides valuable travel services to tourists visiting north eastern states. Red River Tours and Travels is a tour operating wing ofthe Assam Tourism Development Corporation (ATDC) Ltd., which is a Government of Assam undertaking.

The Tour Operators Association of Assam (TOAA) is the apex body of Tour Operators from Assam which was formed on $8^{\text {th }}$ August, 2009. TOAA finally got registered on $16^{\text {th }}$ June 2010. As on December 2019, TOAA has 63 numbers of Active Members. Some of its members are also respected members of the Indian Association of Tour Operators (website of TOAA, accessed on $19^{\text {th }}$ April, 2018)

\section{Literature review}

\section{Challenges before the Private Tour Operators}

Tour operators around the world are facing different challenges which often get reflected in various publications. In a research publication Calveras (2007) stated that increased acceptance of Internet by tourists has reduced the need of intermediation by tour operators. Internet provides the platform for potential tourists to search and communicate with suppliers of different tourism components directly. In another research publication Rajasekaran et al. (2019), the authors have raised the issue of challenges faced by tour operators due to online booking of tours by the tourists which have reduced the income from commission for the tour operators. They further stated that rapid change in technology in the tourism industry often brings new challenge for the tour operators.

Financial challenges faced by tour operators of Tanzania have been portrayed in a publication by Pasape, Mujwiga (2017). Their study on challenges of tour operators reveals that most of the tour operators start business with very low capital and they are too much dependent upon bank loans. Collateral demand by the financial institutions against loans made the financing very difficult. The study further reveals that poor infrastructure support is one of the major obstacles towards delivering of services to the tourists by the tour operators in many African countries.

Political crisis of 2002 in Madagascar had damaged the destination image of the island nation to a great extent. Negative publicity by media on political situation and loss of trust by Inbound Tour Operators were the main reasons behind the damaged image of Madagascar, which was earlier popular amongst the tourists as a destination with rich wildlife and culture. Tour operators had to struggle to win over the trust of tourists here (Rheal, 2016).

Petrak (2012) has referred to Rob Ranking, M.D. of Vagabond Adventure Tour of Ireland who has found it extremely challenging to compete with the increasing number of local competitions 
arising within the industry as more and more unemployed youth got attracted to tour operation business because of two main reasons- one is the growth of tourists to Ireland and second is the relatively easier establishment process of a tour company. Here,Petrak has also referred to Pepe Lopez of ApumayoExpediciones of Peru, who had found it tough to compete with the large international travel companies which generally offered cheaper tour packages taking advantages of large scale operation and tax exemption provided by the local government.

In his research paper Symon (2012)mentioned about the external business environments such as global economic crisis, terrorism etc. that creates challenges to the tour operators operating in Dar-es-Salaam area of Tanzania. Symon has also mentioned about another problem faced by the tour operating companies related to not getting skilled workforce due to unavailability of adequate training facilities in Tanzania.

Imposition of service taxes, introduction of heavy entry fee at many destinations affected inflow of foreign tourists to India during 2003 (Swain, Mishra, 2012).

Another problem faced by tour operators of the Alappuzha area of Kerala is the unavailability of trained and authorized guides in the area which resulted in growth of unauthorized guides escorting tourists to different destinations and charging very high amount of fee (Joseph, 2011).

Bhattacharya (2004) has mentioned the Law and Order situation (then prevailing) of the state of Assam, causing very low private investment in tourism sector. Whatever little had been achieved was mainly concentrated in only transportation sector. Initiative from the state government was lacking in terms of incentives or subsidies granted to establish a new venture in tourism sector. He also mentioned that there is no workforce development program to facilitate adventure tourism activities in the state. The available skilled workforce of Assam Mountaineering Association also remains largely unutilized by tourism industry. Bhattacharya has also mentioned about the lack of quality accommodation on many destinations in Assam, which is a major area of concern for the tour operators dealing with foreign tourists.

\section{Objectives of the study}

The study is designed keeping the following objectives in mind: i) to find out the challenges faced by the Private Tour Operators operating from the state of Assam and ii) to seek solutions to the problems of the Private Tour Operators as far as possible; iii) to highlight these problems in front of the concerned authorities so that they can consider these issues at the time of policy making for improvement of tourism in Assam.

\section{Methodology}

The study is based on both primary and secondary data. Primary data are collectedfrom the offices of 42 Registered Private Tour Operators from three districts of Assam. The Registered Tour Operators have got themselves registered under the Directorate of Tourism, Government of Assam. The three districts chosen are Kamrup (Metro), Golaghat and Bongaigaon. Kamrup (Metro) district has been considered as nearly 75\% of the Tour Operators of Assam operate from this district alone. Golaghat and Bongaigaon districts have been chosen because of tourism activities in and around Kaziranga National Park and Manas National Park respectively. Data are collected by means of personal interviews conducted at the offices of the Tour Oper- 
ators taking help of Question Schedules. Question Schedule is prepared by the researchers of their own incorporating questions based on topics which have global consequences as found during the study of literatures as referred to above and also those topics which are considered important from the local perspective of the study. There are 18 objective type questions with multiple answers and 7 questions with yes or no types of answers to choose from. Also there is one open ended question seeking descriptive answer from the tour operators.

Secondary data such as the list of Registered Private Tour Operators along with their addresses and contact numbers are collected from the office of The Directorate of Tourism, Government of Assam.

\section{Sample size}

The total numbers of active Registered Tour Operators as on May 2018, in the districts of Kamrup (M), Bongaigaon and Golaghat were 46; out of which 44 were from Kamrup (M) and one each from Bongaigaon and Golaghat district. Out of the 46 active Registered Tour Operators in the three districts, 42 Private Tour Operators have been selected as sample for the survey following the Krejcie and Morgan (1970) model of sample size calculation at 95\% confidence level. Lottery method of random sampling has been used to select the sample.

\section{Analysis of data}

The data collected by means of question schedules during the interviews with the tour operators are coded, classified and tabulated in order to calculate some basic statistics such as percentage, average etc. On the basis of the result obtained, generalisations and inferences are drawn in the light of the main objectives of the study which was to find out the challenges faced by the tour operators of Assam.

\section{Findings}

The study reveals many challenges that the Private Tour Operators are facing while operating from the state of Assam. Many of the challenges have local characteristics, but there are some issues which can be considered as global challenges as tour operators of many other countries have experienced similar problems that can be understood from the available literature. Many of the issues are also region specific as tour operators from Assam also operate in other states of India's north eastern region. Therefore a problem associated with Arunachal Pradesh or Nagaland becomes a problem for the tour operators operating from Assam as well. Also it has been observed that many of the problems faced by the Private Tour Operators operating from Assam are common for a large number of them. The apparent variations in some cases are due to differences in organizational setups or types of operations carried out by them. The major challenges faced by the tour operators of Assam as revealed by the study can be jotted down as follows- 
Table 1. Descriptive statistics representing responses of the Private Tour Operators of Assam in relation to some challenges faced by the Private Tour Operators elsewhere

\begin{tabular}{|c|c|c|c|c|c|}
\hline \multirow{2}{*}{ № } & \multirow{2}{*}{ Challenges } & \multicolumn{4}{|c|}{$\begin{array}{l}\text { Tour Operator's Responses } \\
\text { in nos. (in \%) out of } 42 \text { respondents }\end{array}$} \\
\hline & & $\begin{array}{l}\text { Major } \\
\text { Problems }\end{array}$ & $\begin{array}{l}\text { Minor } \\
\text { Problems }\end{array}$ & $\begin{array}{l}\text { Not consider } \\
\text { as problem }\end{array}$ & Not aware of \\
\hline 01 & $\begin{array}{l}\text { Shortage of skilled workforce like Trained Tour Guide, } \\
\text { Tour Manager etc. }\end{array}$ & $\begin{array}{c}24 \\
(57.14)\end{array}$ & $\begin{array}{c}15 \\
(35.72)\end{array}$ & $\begin{array}{c}3 \\
(7.14)\end{array}$ & $\begin{array}{c}0 \\
(0)\end{array}$ \\
\hline 02 & Impact of Terrorism in tourism business & $\begin{array}{c}3 \\
(7.14)\end{array}$ & $\begin{array}{c}8 \\
(19.05)\end{array}$ & $\begin{array}{c}31 \\
(73.81)\end{array}$ & $\begin{array}{c}0 \\
(0)\end{array}$ \\
\hline 03 & $\begin{array}{l}\text { Effect of increase in fuel price on Package pricing and } \\
\text { profitability. }\end{array}$ & $\begin{array}{c}26 \\
(61.90)\end{array}$ & $\begin{array}{c}16 \\
(38.10)\end{array}$ & $\begin{array}{c}0 \\
(0)\end{array}$ & $\begin{array}{c}0 \\
(0)\end{array}$ \\
\hline 04 & $\begin{array}{l}\text { Challenges from large online travel companies (such } \\
\text { as MakeMyTrip) toward your business. }\end{array}$ & $\begin{array}{c}23 \\
(54.76)\end{array}$ & $\begin{array}{c}10 \\
(23.82)\end{array}$ & $\begin{array}{c}9 \\
(21.42)\end{array}$ & $\begin{array}{c}0 \\
(0)\end{array}$ \\
\hline 05 & $\begin{array}{l}\text { Protest from local communities against disturbance } \\
\text { caused by over-tourism. }\end{array}$ & $\begin{array}{c}0 \\
(0)\end{array}$ & $\begin{array}{c}0 \\
(0)\end{array}$ & $\begin{array}{c}16 \\
(38.10)\end{array}$ & $\begin{array}{c}26 \\
(61.90)\end{array}$ \\
\hline 06 & $\begin{array}{l}\text { Lack of parking areas near the destination mainly in } \\
\text { urban areas. }\end{array}$ & $\begin{array}{c}14 \\
(33.33)\end{array}$ & $\begin{array}{c}26 \\
(61.91)\end{array}$ & $\begin{array}{c}2 \\
(4.76)\end{array}$ & $\begin{array}{c}0 \\
(0)\end{array}$ \\
\hline 07 & $\begin{array}{l}\text { Staff Poaching (taking away your trained staff by your } \\
\text { competitor) }\end{array}$ & $\begin{array}{c}27 \\
(64.29)\end{array}$ & $\begin{array}{c}8 \\
(19.05)\end{array}$ & $\begin{array}{c}7 \\
(16.66)\end{array}$ & $\begin{array}{c}0 \\
(0)\end{array}$ \\
\hline 08 & $\begin{array}{l}\text { Acquiring capital for business start-ups or expansion } \\
\text { programmes. }\end{array}$ & $\begin{array}{c}15 \\
(35.71)\end{array}$ & $\begin{array}{c}9 \\
(21.43)\end{array}$ & $\begin{array}{c}15 \\
(35.72)\end{array}$ & $\begin{array}{c}3 \\
(7.14)\end{array}$ \\
\hline 09 & $\begin{array}{l}\text { Increased competition amongst the local tour } \\
\text { operators due to easy process of establishing a tour } \\
\text { company. }\end{array}$ & $\begin{array}{c}9 \\
(21.43)\end{array}$ & $\begin{array}{c}23 \\
(54.76)\end{array}$ & $\begin{array}{c}10 \\
(23.81)\end{array}$ & $\begin{array}{c}0 \\
(0)\end{array}$ \\
\hline 10 & $\begin{array}{l}\text { 'Global climate change' is affecting the Adventure and } \\
\text { Eco- Tourism in your area of operation. }\end{array}$ & $\begin{array}{c}1 \\
(2.38)\end{array}$ & $\begin{array}{c}9 \\
(21.43)\end{array}$ & $\begin{array}{c}11 \\
(26.19)\end{array}$ & $\begin{array}{c}21 \\
(50.00)\end{array}$ \\
\hline 11 & $\begin{array}{l}\text { Demand for Booking of Tours exceeds your capacity } \\
\text { to supply. }\end{array}$ & $\begin{array}{c}14 \\
(33.33)\end{array}$ & $\begin{array}{c}23 \\
(54.76)\end{array}$ & $\begin{array}{c}5 \\
(11.91)\end{array}$ & $\begin{array}{c}0 \\
(0)\end{array}$ \\
\hline 12 & $\begin{array}{l}\text { Supplier of tour services like Transporter, Hotelier, } \\
\text { Restaurants, Guide etc. could not deliver in time. }\end{array}$ & $\begin{array}{c}1 \\
(2.38)\end{array}$ & $\begin{array}{c}22 \\
(52.38)\end{array}$ & $\begin{array}{c}18 \\
(42.86)\end{array}$ & $\begin{array}{c}1 \\
(2.38)\end{array}$ \\
\hline 13 & $\begin{array}{l}\text { Cancellation / delay of Air or Railway Transportation } \\
\text { services create problem in your tour schedule. }\end{array}$ & $\begin{array}{c}1 \\
(2.38)\end{array}$ & $\begin{array}{c}35 \\
(83.33)\end{array}$ & $\begin{array}{c}6 \\
(14.29)\end{array}$ & $\begin{array}{c}0 \\
(0)\end{array}$ \\
\hline 14 & $\begin{array}{l}\text { Lack of training facilities for adventure tourism } \\
\text { organisers in Assam. }\end{array}$ & $\begin{array}{c}9 \\
(21.43)\end{array}$ & $\begin{array}{c}12 \\
(28.57)\end{array}$ & $\begin{array}{c}4 \\
(9.52)\end{array}$ & $\begin{array}{c}17 \\
(40.48)\end{array}$ \\
\hline 15 & $\begin{array}{l}\text { Lack of promotional activities by concerned } \\
\text { departments. }\end{array}$ & $\begin{array}{c}32 \\
(76.19)\end{array}$ & $\begin{array}{c}6 \\
(14.28)\end{array}$ & $\begin{array}{c}1 \\
(2.38)\end{array}$ & $\begin{array}{c}3 \\
(7.15)\end{array}$ \\
\hline
\end{tabular}

Source: Survey conducted by the Researcher

Around 92\% of Private Tour Operators operating from Assam consider shortage of skilled workforce as a challenge for their business. Shortage of trained workforce like guides with multiple language skills, trained tour managers, hotel staffs are considered as 'major problems' by $57 \%$ of the operators. Though Assam and a few other states from north east India were hard hit by the insurgency related problems in the recent past, $74 \%$ of the tour operators from Assam do not consider the issue of terrorism as a problem for tourism activities in the state in the present scenario. Almost all the tour operators from the state consider the rapid increase in the prices offuel as a big challenge to keep the prices of their Package Tour in the lower side. Large online travel companies like MakeMyTrip.com, Yatra.com etc. have brought challenges for small size tour operators from Assam. 54\% of the tour operators consider it as major issue, while $24 \%$ operators consider it as minor problem. Another $21 \%$ operators do not consider it as a problem; 
they rather consider it as an opportunity for them to be more competitive. There have been few incidents reported from some parts of India where local communities have started raising their voices against over-tourism in their locality. But in Assam 38\% of the Tour Operators do not consider it as a problem in this state and another $62 \%$ of the operators are not aware of any such situation here in north east India. Lack of parking areas in many destinations around Shillong and Guwahati cities and also far off places like Dawki (near Indo-Bangladesh border in Meghalaya) during peak season, create problems for the Tour Operators to park their vehicles as per opinion of nearly $95 \%$ of the operators. 'Staff Poaching' has been considered as a routine problem for nearly $83 \%$ of Private Tour Operators from Assam. 64\% amongst them consider it as a major problem. Nearly $57 \%$ of tour operators operating from Assam faces the problem of acquiring capital for startups and expansion programs. While $36 \%$ do not consider it as a problem.The easy process of acquiring a license from the state tourism department and requirement of minimum assets to start a travel company has encouraged many youths towards this occupation. It results in increased competition at local level as per opinion of $76 \%$ of tour operators from Assam. 50\% of the tour operators have no idea about the impact of 'Global Climate Change' in Adventure Tourism and Eco-Tourism activities in the North East India. While 23\% of the operators feel that Global Climate Change has started creating problem for the tourism industry in this region in terms of unpredictable weather conditions like unseasonal rainfall, severe flooding etc. It certainly disturbs the adventure and eco-tourism activities. Over bookings during peak seasons, especially for those tour operators taking tourists to Jeep and Elephant safaris at Kazaringa and Manas National Parks in Assam, find it difficult to fulfill the demands of the tourists on many occasions due to limitations on entry and exit of tourists inside the parks on daily basis. Finding quality hotels during peak seasons at faraway destinations like Tawang in Arunachal Pradesh do create challenges for the tour operators. Unable to provide desired services on time by some suppliers related to tours, create problems for the tour operators as expressed by $54 \%$ of them doing business here from Assam. While $43 \%$ of the operators do not consider it as a problem, as they can manage such situation under control by simply cancelling their booking with such suppliers in the next tourism season. Nearly $86 \%$ of tour operators have expressed that cancellation or delay of Air and Railway transportation services create problems in conducting the tour as per planned schedule. Some last minute adjustments have to be done in the itineraries because of pre-bookingof services related to tours.

$50 \%$ of the tour operators feel that lack of training facilities for Adventure Tourism activities in Assam create problems for tour operators who want to offer services in that segment of tourism. $40.48 \%$ of operators were unable to response as they do not provide services in Adventure Tourism. Lack of promotional activities by the concerned government departments for the development of tourism in Assam has been an area of concern for 90\% of Private Tour Operators operating from Assam. 
Table 2. Descriptive statistics in relation to some local challenges faced by the Private Tour Operators from Assam

\begin{tabular}{|c|l|c|c|c|c|}
\hline \multirow{2}{*}{ № } & Challenges & \multicolumn{3}{|c|}{ Tour Operator's Responses in nos. (in \%) out of } \\
\cline { 2 - 5 } & & Yes & $\%$ & No & $\%$ \\
\hline 01 & High cost of acquiring \& renewing License. & 1 & 2.38 & 41 & 97.62 \\
\hline 02 & Higher Operational cost & 31 & 73.81 & 11 & 26.19 \\
\hline 03 & High rate of Taxation (GST) on the services provided by you & 22 & 52.38 & 20 & 47.62 \\
\hline 04 & Bad road condition for movement of tourists in Assam & 31 & 73.81 & 11 & 26.19 \\
\hline 05 & Bad International air connectivity in Assam & 33 & 78.57 & 9 & 21.43 \\
\hline 06 & Frequent Bandh (strikes) called by different organizations & 27 & 64.29 & 15 & 35.71 \\
\hline 07 & Lack of quality hotels and other accommodations except Guwahati city & 19 & 45.24 & 23 & 54.76 \\
\hline
\end{tabular}

Source: Survey conducted by the Researcher

The cost of operation in Assam and other north eastern states are comparatively higher than many other Indian states due to high transportation and food cost as expressed by $74 \%$ of tour operators. It directly has an impact on the price of Tour Packages. 52\% of tour operators feel that the rate of taxation (GST) on their services are little higher under the competitive environment. Bad road conditions for movement of tourists to many destinations in Assam are considered as a problem by $73.81 \%$ of tour operators. $78.57 \%$ of the tour operators, especially those who serve foreign tourists, face the problem of poor international air connectivity to the state. Frequent 'Bandh' (strikes) called by different political and non-political organizations in Assam is a big challenge for the tour operators of Assam as expressed by $64 \%$ of operators. Lack of quality accommodation facilities in many destinations of north eastern states of India, except in major cities like Guwahati and Shillong, create problems for tour operators who handle high end tourists.

Table 3. Descriptive statistics in relation to ease of establishing a travel company in Assam by the Private Tour Operators

\begin{tabular}{|c|l|c|c|c|c|}
\hline \multirow{2}{*}{ № } & \multirow{2}{*}{$\begin{array}{l}\text { Statements: } \\
\text { (how easy or tough was their experiences in the following cases) }\end{array}$} & \multicolumn{3}{|c|}{$\begin{array}{c}\text { Tour Operator's Responses } \\
\text { in nos. (in \%) out of 42 respondents }\end{array}$} \\
\cline { 3 - 6 } & & Very Tough & Tough & \multicolumn{2}{|c|}{$\begin{array}{c}\text { Easy } \\
\text { Very Easy }\end{array}$} \\
\hline 01 & Acquiring/ renewing of license from concerned authority & $\begin{array}{c}1 \\
(2.38)\end{array}$ & $\begin{array}{c}12 \\
(28.57)\end{array}$ & $\begin{array}{c}29 \\
(69.05)\end{array}$ & $\begin{array}{c}23 \\
(0)\end{array}$ \\
\hline 02 & Getting Loan from Bank to start business & $(19.05)$ & $(54.76)$ & $\begin{array}{c}11 \\
(26.19)\end{array}$ & $\begin{array}{c}0 \\
(0)\end{array}$ \\
\hline 03 & Getting room for office in a central location & 3 & 35 & 4 & 0 \\
$(7.14)$ & $(83.33)$ & $(9.53)$ & $(0)$ \\
\hline
\end{tabular}

Source: Survey conducted by the Researcher

Acquiring or renewing of licenses from the Directorate of Tourism, Assam is found to be an easy task by $69.05 \%$ of tour operators; hence, they don't consider it as a problem in their business. Getting loans against the company's name, without much fixed assets to offer as security, has been a major problem, especially for the small scale and new tour operators operating from the state. Getting room for office at a central location, mainly in the capital city of the state where from most of the tour operators operate or at least have a branch office, is considered as difficult exercise for nearly $90 \%$ of the operators. 
During the interactions with the Private Tour Operators following issues were also got mentioned as potential challenges:

- Problem of Off-season, considered as a global issue associated with Tourism Industry, has also troubled the tour operators of Assam. Assam has a long off-season period starting from the month of March till the end of August. Many operators have no option but to wait and watch for the next session. The burden of paying staff, office rent, interest on loans taken, without any major output is a big problem for majority of operators.

- Slow speed in data transfer, unavailability of mobile network etc. are some common problems in many destinations of Northeast India. It is a big issue for those operators who send foreign tourists to such locations. Foreign tourists want good internet connectivity during their tour especially when they are resting at their hotels, resorts or home stay facilities. Couples of tour operators have been bold enough to charge the officials of government tourism department of not listening to the practical suggestions placed by the operators in different meetings of the stakeholders. Many of the decisions taken by the concerned departments are impractical.

\section{Discussions and suggestions}

The study has revealed that the tour operators operating from Assam are facing numerous challenges. Some of the challenges can be dealt with by bringing changes in their internal operational mechanism and by creative and careful planning. But there are some challenges for which the tour operators cannot do much at their level, except requesting the concerned government departments for their solutions. Again there are some challenges which are directly related to nature; for those issues tour operators have to adjust their business strategies according to the situation as it comes. Following suggestions are forwarded to address some of the issues:

\section{Recommendation for tour operators for the development of new products:}

- As the domestic tourism market in Assam is increasing at a good pace over the last decade or so, tour operators should create more products keeping in mind the taste of domestic tourists. Packages based on religious tourism can be one good option.

- Tour operators should try to promote new destinations to minimize the problem of overbooking in established destinations during peak season. To facilitate accommodations during peak season Home Stay facilities, Outdoor Eco-camps should be explored.

- Monsoon Tourism can be promoted in destinations like Shillong, Cherrapunji and Tea garden areas of Upper Assam to provide tourists a place to relax during rainy season which is also the long holiday season for schools and colleges. It will provide an opportunity to the operators to shorten the long off-season period in the industry.

- The state of Assam possess large natural lakes, rivers, low altitude hills, vast grass land suitable for Adventure Tourism activities like Rafting, Parasailing, Paragliding, Tracking, River Cruising, Water Sports etc. Tour operators should focus on creating more Adventure Tourism opportunities in Assam.

- Many reputed private schools from the state regularly send their students to other states on educational tours. Moreover Government of Assam has been providing financial assistance to the students of colleges across Assam to go on educational trips for the 
last few years. Tour operators have a very good opportunity to expand their business in educational tour segment.

- Private Tour Operators can work together with the major hospitals in Guwahati, Government agencies, airlines, hotels etc. for the promotion of Health Tourism in Assam as Guwahati city has been developing into a 'Health City' with the establishment of many super specialty hospitals and the upcoming All India Institute of Medical Sciences (AIIMS).

- While preparing package tour, innovation and creative thinking is a necessary ingredient for its success. Tour operators can take help of experienced consultancy firms regarding content development, pricing and presentation of the tour packages.

\section{Recommendation for tour operators to improve marketing of tours:}

- To enhance marketability and at the same time to minimize competition amongst the local operators, the tour operators should try to build their image as specialist operators on a particular segment of tourism, rather than general operators offering all short of packages.

- For the Tour Operators who cater to the Inbound Tourists, a joint promotional strategy should be initiated by different associations of tour operators of North East India in those countries which traditionally produce large number of Inbound Tourists to the region. A joint promotional campaign can be economical and beneficial for all operators of the region as tourists generally visit different states of North East during a single trip.

- Tour operators must create resources to invest in latest technologies to counter the penetration of large online companies in the market. Small tour operators often do not have sufficient fund to invest in those technologies; but they must generate some funds for investment in technologies on priority basis to be able to survive.

- Tour operators must create Dynamic Websites through which real time information sharing, instant tour booking etc. will be possible. The website should support mobile phones as most people use cell phones to surf internet or to make online payments.

- Having a presence in social media such as Facebook, Instagram or WhatsApp should be considered as basic requirement by the tour operators. These are the tools to keep in touch with the loyal customers and also to find new ones with minimum investment.

- As demand for wildlife and Cultural Tourism (Tribal Tourism) is very high amongst the foreign tourists visiting North East, a coordinated effort between the tour operators of north eastern states especially Assam, Arunachal Pradesh and Nagaland can be beneficial for everyone. They can share ground operations amongst themselves through some mutual arrangement.

\section{Recommendation for Private Tour Operators to improve quality of services:}

- By engaging Degree, Diploma or MBA qualified personnel from tourism background in the positions of Tour Managers, Marketing Managers etc., the tour operators can receive some fresh inputs on the latest developments taking place in global tourism industry.

- Tour operators should engage only licensed Guides for the tourists who have opted for their services. A qualified Guide, preferably local, can explain better about the culture, 
history and people associated with the destination and give the tourists full satisfaction of the tour.

- Taking feedback from tourists after a tour is a good practice that should be adopted by all tour operators. Analysis of feedback can provide practical assessment of the quality of services provided to tourists by the tour operators. Corrective measures can be initiated from those feedbacks. Good comments received should be highlighted in the Website of the company.

- Online reviews and ratings about the services of tour operators should be regularly monitored. Acknowledgement for good review and justification against any bad comment should be given as far as possible as many prospective customers would see the reviews before approaching a tour operator.

- Tour operators should try to attend maximum number of tourism fairs, conferences, fam-tours. It would help in developing their market as they would meet large number of travel agents, tourists, tour operators, travel writers during that period. Tour operators can enhance their knowledge about various practices adopted by other tour operators too.

- While finalizing agreements with restaurants, Dhabas etc. for serving food to the tourists during a tour, tour operators should make no compromise on quality of food served. Maintenance of hygiene and cleanliness, availability of sealed drinking water bottles, availability of water in toilets etc. should be made criteria for accepting or rejecting contracts with the restaurants.

Recommendation for tour operators to counter the threat received from large online travel companies:

- Tour operators should adopt latest technologies such as having a dynamic website, facilitate online bookings through smart phones, and update activities through Facebook, Tweeter etc. to reach more and more techno-savvy customers.

- Keep the existing tourists base intact by regularly keeping in touch with them through social media and personal contacts.

- Tour operator should try to project oneself as specialised tour operator with good knowledge of local conditions.

- Never to compromise with the quality of services.

- Try to be creative in products and services and offer something new to the tourists.

\section{Recommendation for tour operators on some other issues:}

- To fulfill the shortfall of skilled workforce in tourism industry, the Association of Tour Operators can organize seminars to discuss such issues with the educational institutions offering courses on Tourism Studies, institutions offering training to Guides, Skill Development Centers etc. Officials from the Directorate of Tourism should also be invited to such seminars. A collective effort can solve the problem.

- The issue of 'staff poaching' should be raised at the tour operators' forum. Action can be initiated to disqualify such operators from membership of the forum who is found to be indulging in such unethical activities.

- Diversification of business has been practiced by maximum established business houses around the world to absorb market ups and downs better. Tour operators also can 
diversify their business in many areas like establishment of resorts, restaurants, travel agency, car rental business etc. according to their abilities and choices.

\section{Recommendation for the concerned government departments and policy makers of tourism in Assam:}

- Poor mobile network and internet connectivity problems in many locations of the state should be addressed by the concerned department on a priority basis to help tourists, especially the business travellers, to perform their usual business when they are halting for a night.

- The State Tourism Department should help the tour operators from Assam to take advantage of the initiative taken by Government of India to promote cultural and economic ties with the ASEAN nations through the Act East Policy. It should facilitate discussion between tour operators of Assam and their counterparts in ASEAN countries to chalk out plans for two way movement of tourists between these countries.

- The Goods and Services Tax charged by both the State and Central government on the various components of the tourism services should be reduced so that the prices of package tours can be kept low by the tour operators to attract more tourists.

- The roads to various destinations should be maintained in good conditions especially after the rainy season in order to facilitate smooth movement of tourists.

- The process of developing a Regional Air Hub at LGBI Airport at Guwahati should be carried out in a systematic, sustainable and time bound manner for the long term benefit of tourism in the entire North East of India.

- Government should work out some schemes to provide bank loans at subsidized interest rates for the needy tour operators for starting or expanding business.

\section{Conclusion}

The study has led us to the conclusion that Private Tour Operators operating from Assam have to face different challenges while performing their services. Some of the issues are vary localized in nature while many others are general nature experienced by other tour operators across different countries. Again issues like global warming impacting adventure and eco-tourism in many parts of the world has not shown much impact on tourism business in Assam as yet. Major problems faced by the operators from this region are coming from two areas- firstly, inadequate infrastructure facilities for tourism in the destinations and secondly, tour operators are not adopting the latest technological facilities in their day to day business activities.

The internal problems faced by the tour operators can be minimized by careful planning and bringing little changes in the operational strategies at the organizational level. Tour operators should concentrate on adopting latest technologies and being more innovative in creating unique tour package incorporating local characteristics. Regarding external challenges like poor infrastructure, annual flood, the tour operators could not do much besides adopting the situation as it unfolds while being innovative in their business strategies. The state government has to create the necessary infrastructure for the development of tourism in the state as there is very little private investment coming in tourism sector. Moreover government should take all necessary steps to make available capitals at subsidized interest rates for the needy tour operators. 
The tour operators operating from Assam havealso been instrumental in the development of tourism activities in the north eastern states bordering Assam. Their long experiences in dealing with international and domestic tourists through Kaziranga National Park put them in anadvantageous position over their counterparts of other north eastern states. They have been successful to some extent to draw the attention of domestic and international travelers. But they still have lots of ground to cover. The ongoing developmentat the Lokpriya Gopinath Bordoli International Airport at Guwahati to convert it into a truly international standard airport, also creating a domestic air operation hub for the North East at the same airport will surely facilitate easy movement of tourists within the states of North East. To trap the ASEAN market the tour operators from the region should come together to chalk out some strategies to jointly promote the destinations of the region and should try to work in a collaborative environment for the greater interest of tourism.

\section{Acknowledgement}

We would like to appreciate the Directors, Managers and other officials of the Private Tour Operators covered under the study who have willingly co-operated with the study by providing valuable inputs and suggestions and also shared their valuable time with us during the interviews.

The office of The Directorate of Tourism, Government of Assam should be offered especial thanks for providing the list of Private Tour Operators registered under them.

\section{References}

Aziz, R.C., Hashim, N.A.A.N., Awang, Z. 2018. Tourism Development in Rural Areas: Potentials of Appreciative Inquiry Approach. Journal of Tourism, Hospitality \& Culinary Arts $10(1), 59-75$.

Bhattacharya, P. 2004. Tourism in Assam: Trend and Potentialities. Bani Mandir, Guwahati, $1^{\text {st }}$ Edition.

Calveras, A. 2007. What do Tour Operators do? Internet and the economics of intermediation in the tourism industry. [online] accessed at: https://www.researchgate.net/publication/228309527 What Do Tour Operators Do Internet and the Economics of Intermediation in the Tourism Industry [Accessed in Feb. 2018]

Chaudhuri, T. 2012. Cultural Tourism: A critical building block towards sustainable environment in Sikkim. Online International Interdisciplinary Research Journal 2(2), 134-139.

Ganie, S. A., Dar, M.A. 2020. Role of Human Resources in the Tourism Industry with Special Reference to Jammu and Kashmir. Turizam 24 (2), 68-78.

Holden, A. 2005. Tourism Studies and the Social Sciences. Routledge, Taylor \& Francis e-Library, available at http://taylorfrancis.com [accessed on 24 May 2019].

Josheph, J. 2011. A Critical Analysis of the measures initiated by the Government and Private Agencies for the Promotion of Tourism in Alappuzha, Ph.D. Thesis, School of Gandhian Thought and Development Studies, Mahatma Gandhi University, Kottayam. (online) accessed at https://shodhganga.inflibnet.ac.in/handle/10603/25837 [assessed in Feb. 2018].

Khanna, S., Khajuria, S. 2016. Tourism Impact and Support for Future Development: Local's Perspective at Ambaran Village. Journal of Tourism, Hospitality E Culinary Arts 8(2), $10-21$. 
Krejcie, R.V., Morgan, D.W. 1970. Determining Sample Size for Research Activities. Educational and Psychological Measurement 30(3), 607- 610.

Kunjuraman,V., Hussin, R., Ahmad, A. R. 2015. International Tourist Satisfaction towards Tourism Activities and Facilities: A Case Study in Mamutik Island, Kota Kinabalu, Sabah, East Malaysia. Journal of Tourism, Hospitality and Culinary Arts 7(1), 76-92.

Lawton, L.J., Weaver, D.B. 2009. Travel Agency Threats and Opportunities: The Perspective of Successful Owners. International Journal of Hospitality \& Tourism Administration 10(1), 68-92.

Murugan, A. 2005. Challenges and changes in Indian Tourism. South Asian Journal of Socio Political Studies 6(1), 103-106.

Okharedia, A.A. 2017. Promoting tourism in developing economies: challenges and prospects. African Journal of Hospitality, Tourism and Leisure 6(1), 1-11.

Pasape, L., Mujwiga, S. 2017. Towards success of ecotourism networks in Tanzania: a case of Tanzania Association of Tour Operators. Journal of Hospitality Management and Tourism 8(2), 14-24.

Petrak, N. 2012. Behind the Scenes: ATTA Tour Operators Share Challenges, Trends and Opportunities. Adventure Travel News, ATTA, (online) accessed at https://www.adventuretravelnews.com/what-is-the-biggest-challenge-threat-adventure-travel-organizations-likeyours-face-in-the-next-18-months [accessed in Oct. 2017].

Rajasekaran, R., Tayal, M.A., Kanimozhi, D. 2019. Opportunities and Challenges in E-marketing with reference to Tourism Industry in India. International Journal of Research in Business Studies 4(1), 49-62.

Raju, G.P. 2009. Ecotourism Guidance for Tour Operator. Mangalam Publications, Delhi.

Raluca, D.C., Gilet, S.G., Stefania, M.C. 2013. The challenges of tour operators facing the promotion of Romanian destinations. Romanian Economic and Business Review 8(4.1), 317326.

Rao, M.B. 2007. Tourists' Perception Towards Package Tours. Indian Journal of Marketing 37(5), 28-31.

Razzaq, A.R.A., Hadi, M.Y., Mustafa, M.Z. 2011. Local community participation in homestay program development in Malaysia. Journal of Modern Accounting and Auditing 7(12), 1418-1429.

Register of Tour Operators at the office of Directorate of Tourism, Government of Assam, [accessed on May 2018].

Rheal, L. A. 2016. The perceived challenges of incoming tour operators with the post political crisis effects in Madagascar. Thesis submitted to the Norwegian School of Hotel management, University of Stavanger.

Rizal, P., Asokan, R. 2013. A Comparative Study of Tourism Industry in North-Eastern States of India. IOSR Journal of Business and Management 12(4), 56-62.

Sharma, J.K. 2007. Tourism Products and Services. Kanishka Publishers, New Delhi.

Sivakumar,V., Saranya, P.R., Iyappan, A., Leelapriyadharsini, S. 2019. A preliminary review of the cultural heritage and emerging pilgrimage tourism in Tamil Nadu. Journal of Tourism, Hospitality \& Culinary Arts 11(2), 94-105.

Swain, S.K., Mishra, J.M. 2012. Tourism-Principles and Practices. Oxford University Press, New Delhi.

Symon, N. 2012. Challenges of Tour Operators, Case Study: Dar-es-Salaam, Tanzania. Thesis submitted to Haaga-Helia University of Applied Science. (online) Accessed at: https:// 
www.theseus.fi/bitstream/handle/10024/49071/CHALLENGES\%20OF\%20TOUR\%20 OPERATORS-SYMON\%2oNKONOKI.pdf, [accessed in December 2017].

Vujičić, M. 2019. The Role of Tourism and the Importance of the Stakeholder Approach in Creating Team Building Programs. Turizam 23(3), 157-165.

World Travel \& Tourism Council. 2018. Travel \& Tourism Economic Impact. WTTC, London. World Tourism Organization. 2018. Tourism and Cultural Synergies. UNWTO, Madrid. Internet 1: http://www.toaa.in; official website of Tour Operators Association of Assam (TOAA), [assessed in April, 2018]. 